\title{
PHYSIOLOGICAL AND BIOCHEMICAL CHANGES IN BRAZILIAN PEPPER (Schinus terebinthifolius Raddi) SEEDS DURING STORAGE ${ }^{1}$
}

Lucas PInto Ribeiro², Argemiro Teixeira Leite Filho², Luana Bertollini de Jesus Silva², Valeria Fátima Silva² and Eduardo Euclydes de Lima e Borges ${ }^{3 *}$

${ }^{1}$ Received on 16.12.2016 accepted for publication on 31.10.2017.

${ }^{2}$ Universidade Federal de Viçosa, Programa de Pós-Graduação em Engenharia Florestal, Viçosa, Minas Gerais - Brasil. Email:<argemirotlf@gmail.com>,<luanabertollini17@gmail.com>, <ribeirolucaspinto@gmail.com> and < valeria.fatima@ufv.br>.

${ }^{3}$ Universidade Federal de Viçosa, Departamento de Engenharia Florestal, Viçosa, Minas Gerais - Brasil. E-mail: <elborges@ufv.br>.

*Corresponding author.

ABSTRACT - Seed propagation is the standard method of propagation of Brazilian peppertree (Schinus terebinthifolius Raddi); therefore, the study of appropriate conditions of seed storage is of great importance. The aim of this study was to quantify the physiological and biochemical changes that occur in Brazilian pepper seeds under different storage conditions. Seeds were stored at $34,55,75$, and $93 \%$ relative humidity (RH) at $20^{\circ} \mathrm{C}$. Samples were collected before storage and every two months for the analysis of moisture content, germination percentage, germination rate, lipid peroxidation, membrane permeability, and activity of enzymes of the antioxidant system. Brazilian pepper seeds remained viable for 12 months when kept at 34 or 55\% RH. At $75 \% \mathrm{RH}$, seeds lost viability in six months, whereas at $93 \% \mathrm{RH}$, seeds deteriorated within two months. Electrical conductivity and lipid peroxidation decreased after eight months of storage under all RH conditions. No relation was observed between loss of physiological quality and lipid peroxidation or membrane permeability. The activity of the enzymes superoxide dismutase, catalase, and ascorbate peroxidase did not vary during storage, regardless of $\mathrm{RH}$.

Keywords: Antioxidant system; Germination; Electrical conductivity.

\section{MUDANÇAS FISIOLÓGICAS E BIOQUÍMICAS EM SEMENTES DE AROEIRA- VERMELHA (SCHINUS TEREBINTHIFOLIUS RADDI) DURANTEO ARMAZENAMENTO.}

\begin{abstract}
RESUMO - Aroeira-vermelha tem as sementes como o principal meio de propagação da espécie, justificando o estudo de meios apropriados de armazená-las. Esta pesquisa objetivou a quantificação das alterações fisiológicas e bioquímicas nas sementes nos diferentes ambientes de armazenamento. Para isso, as sementes foram armazenadas em 34, 55, 75 e 93\% de umidade relativa (UR) a $20{ }^{\circ} \mathrm{C}$. Antes do armazenamento $e$ a cada dois meses foram retiradas amostras e determinadas os teores de água e de germinação, o indice de velocidade de germinação, a peroxidação de lipídios, a alteração na permeabilidade da membrana e as atividades de enzimas do sistema antioxidante. As sementes morrem em UR de 93\% em dois meses, enquanto em $75 \%$ UR a perda de viabilidade ocorre em seis meses. Nas demais condições a qualidade fisiológica permaneceu sem grandes variações. A condutividade elétrica e a peroxidação de lipídios tenderam à redução em todos os ambientes e em todas as umidades relativas, respectivamente, após oito meses. As atividades das enzimas superóxido dismutase (SOD), catalase (CAT) e ascorbato peroxidase (APX) não variaram ao longo do tempo em qualquer condições de UR. Conclui-se que sementes de aroeira-vermelha conservam o vigor por 12 meses quando mantidas em URs de 33 e 55\%. Em UR de 93\% resulta em deterioração das sementes em dois meses. Em UR de $75 \%$ a perda de qualidade reduz em seis meses e não há relação entre a perda de qualidade fisiológica da sementes com a peroxidação de lipídios ou a permeabilidade de membrana.

Palavras-Chave: Sistema antioxidante; Germinação; Condutividade elétrica.
\end{abstract}




\section{INTRODUCTION}

Schinus terebinthifolius Raddi, popularly known as Brazilian peppertree, is found in many Brazilian states, from Rio Grande do Sul to Pernambuco. This plant has many bioactive and phytochemical properties (Guerra et al., 2000; Amorim and Santos, 2003). Because of its high ecological plasticity, Brazilian peppertree can be grown in different regions of Brazil (Lenzi and Orth, 2004). For germination tests, $25^{\circ} \mathrm{C}$ is the recommended temperature for this species (Amaral, 1984).

Metabolic reactions that occur during seed germination and storage lead to the production of reactive oxygen species (ROS). According to Bailly et al. (2008), ROS act as signaling and toxic substances during stress situations and during storage. Seed aging leads to lipid peroxidation, which in turn can promote membrane disruption, as verified by Flávio and Paula (2010) in Dictyoloma vandellianum seeds. Changes in membrane permeability as a result of aging lead to electrolyte leakage. Ataide et al. (2016) reported an increase in electrical conductivity of Dalbergia nigra seeds caused by lipid peroxidation and deterioration. According to the authors, lipid peroxidation increased in seeds stored at $93 \% \mathrm{RH}$ and remained stable at $55 \% \mathrm{RH}$. The increase in lipid peroxidation has been used as an indicator of oxidative stress in Phaseolus vulgaris during storage (Sadeghipour and Aghaei, 2012).

The antioxidant system of plants is activated to prevent ROS from reaching toxic levels. Peroxidase (POX), ascorbate peroxidase (APX), superoxide dismutase (SOD), and catalase (CAT) are enzymes involved in the elimination of ROS (Mittler, 2002; Scandalios, 2005). Reduction in CAT activity was associated with lipid peroxidation and loss of seed quality in Pterogynes nitens (Ataide et al., 2012). A reduced CAT activity was also related to loss of seed quality in Melanoxylon brauna seeds stored for 12 months in a cold chamber. However, SOD activity varied between compartments in this species, remaining constant in the embryonic axis and increasing in the cotyledons during the 12 months of storage (Corte et al., 2010). Ultra-dry storage of Jatropha curcas seeds promoted an increase in CAT, SOD, and APX activities, a reduction in lipid peroxidation, and, consequently, a reduction in the rate of seed deterioration (Cui et al., 2014)

Considering the importance of information on adequate storage conditions, this study aimed to evaluate the physiological and biochemical changes that occur in Brazilian pepper seeds during storage under different RH conditions.

\section{MATERIALAND METHODS}

Brazilian pepper berries were obtained from the company Agrorosa (São Mateus, Espírito Santo) and sent to the Laboratory of Analysis of Forest Seeds of the Federal University of Viçosa in 2012. The berries were sun-dried until they opened. Immature, deteriorated, or damaged seeds were eliminated. For each RH condition, seeds were organized in 10 groups of approximately 800 seeds each, packed in nylon bags. The bags were kept at a constant temperature $\left(20^{\circ} \mathrm{C}\right)$ in desiccators containing saturated salt solutions for humidity control, as shown in Table 1. The storage method described by Borges et al. (2009) was adopted. Seeds had an initial moisture content of approximately $10 \%$. Every 15 days, bags were shifted inside the desiccators to avoid stratification of humidity.

To evaluate changes during storage, analyses were performed every two months during the 12-month period on stored seeds and freshly harvested seeds (time zero, no storage, used as controls). Moisture content, germination percentage, germination rate, electrical conductivity, lipid peroxidation, and the activities of CAT, APX, and SOD were quantified at each collection.

Moisture content was determined by oven drying samples at $105 \pm 3{ }^{\circ} \mathrm{C}$ for $24 \mathrm{~h}$ (Brasil, 2009) in three replicates ( 30 seeds per replicate). Results were expressed as percentage of fresh weight base.

Seeds were placed in Petri dishes double-lined with germitest-type paper moistened with $4.0 \mathrm{~mL}$ of distilled water and kept in a germinator at $25^{\circ} \mathrm{C}$. Seeds were kept under constant light for 10 days using four $40 \mathrm{~W}$ fluorescent lamps. Water was added to the germination paper during the course of the study whenever necessary. Germination was determined by the daily count of radicle protrusion, and results were

Table 1 - Relative humidity (RH) obtained using saturated salt solutions at $20^{\circ} \mathrm{C}$

Tabela 1-Umidades relativas (UR), em porcentagem, obtidas em soluções saturadas de sais para a temperatura de $20{ }^{\circ} \mathrm{C}$.

\begin{tabular}{lr}
\hline SALT & RH (\%) \\
Magnesium chloride $\left(\mathrm{MgCl}_{2} \cdot 6 \mathrm{H}_{2} \mathrm{O}\right)$ & 34 \\
Calcium nitrate $\left(\mathrm{Ca}\left(\mathrm{NO}_{3}\right)_{2}\right)$ & 55 \\
Sodium chloride $(\mathrm{NaCl})$ & 75 \\
Ammonium phosphate $\left(\mathrm{NH}_{4} \mathrm{H}_{2} \mathrm{PO}_{4}\right)$ & 93 \\
\hline
\end{tabular}

Revista Árvore. 2018;42(1):e420105 
expressed as mean percentages. The germination rate (GR) was calculated by the formula proposed by Maguire (1962). Tests were conducted using a completely randomized design. A qualitative data analysis was performed. Data are presented as experimental values and standard errors.

Membrane integrity was evaluated in five replicates of 50 seeds each. Samples were placed in Erlenmeyer flasks with $70 \mathrm{~mL}$ of distilled water at $20^{\circ} \mathrm{C}$ for $18 \mathrm{~h}$, according to the method previously tested and adapted from Marques et al. (2002). The electrical conductivity of the leachates was determined using a conductivity meter (cell constant, $\mathrm{K}=1.0$ ).

Lipid peroxidation was evaluated spectrophotometrically by determining the thiobarbituric acid index (TBA-i), as described by Araújo (1994). Analysis was performed in three replicates of 50 seeds each.

The crude enzyme extracts for the determination of SOD, CAT, and APX activities were obtained by maceration of $0.1 \mathrm{~g}$ of decoated seeds on ice, followed by the addition of $2.0 \mathrm{~mL}$ of the homogenization medium: $0.1 \mathrm{M}$ potassium phosphate buffer (pH 6.8), $0.1 \mathrm{mM}$ ethylenediaminetetraacetic acid(EDTA), 1 mM phenylmethanesulfonyl fluoride (PMSF), and $1 \%(\mathrm{w} / \mathrm{v})$ polyvinylpolypyrrolidone (PVPP). The extract was then centrifuged at $15,000 \times g$ for $15 \mathrm{~min}$ at $4{ }^{\circ} \mathrm{C}$ (Flores et al., 2014). Three replicates of 50 seeds were used for the extractions, and aliquots were taken to quantify enzyme activity.

SOD activity was determined according to procedures proposed by Del Longo et al. (1993) and Giannopolitis and Ries (1977) and quantified according to Beauchamp and Fridovich (1971). Three replicates were performed per treatment, in triplicate.

CAT activity was determined according to Havir and McHale (1987). The enzymatic activity was calculated using the molar extinction coefficient of $36 \mathrm{M} \mathrm{cm}^{\prime \prime}$ (Anderson et al., 1995). Three replicates were performed per treatment, in triplicate.

APX activity was determined by the method described by Ramalheiro (2009). Three replicates were performed per treatment, in triplicate.

Protein content was determined according to the method proposed by Bradford (1976) using a standard curve of bovine serum albumin (BSA). Each treatment consisted of five replicates.

\section{RESULTS}

Moisture contents of seeds are shown in Figure 1. Seeds stored at 93\% RH had an increase in moisture content. Treatment under this condition was discontinued after two months because of seed deterioration. The moisture content of seeds at $75 \% \mathrm{RH}$ remained practically constant, having small variations throughout the storage period, which indicates that seeds reached hygroscopic equilibrium. At $55 \% \mathrm{RH}$, there was a continuous decrease in moisture content from the second month onward, whereas at $34 \% \mathrm{RH}$, the moisture content of seeds stabilized, indicating hygroscopic equilibrium.

There was a decrease in the percentage of germination at $93 \% \mathrm{RH}$ in two months, when seed death was evidenced by softening of the seeds and mold proliferation (Figure 1). At $75 \% \mathrm{RH}$, decrease in germination percentage only occurred from the eighth month onward, whereas at 34 and $55 \% \mathrm{RH}$, there was no significant variation in this parameter.

GR of seeds stored at 93\% RH decreased in the second month of storage, similar to the observed for germination percentage (Figure 1). During the same period, there was an increase in GR of seeds stored under the other conditions. After the second month, there was a marked reduction in GR of seeds at $75 \% \mathrm{RH}$, whereas GR remained stable throughout the storage period at 34 and 55\% RH.

The electrical conductivity of seeds kept at $93 \% \mathrm{RH}$ increased in two months of storage (Figure 2). In the other conditions, there was a decrease in conductivity in the first two months. The conductivity of seeds kept at $34 \% \mathrm{RH}$ remained low in comparison with that of other seeds during the entire observation period. At 55 and $75 \% \mathrm{RH}$, conductivity values increased until reaching similar values to those of the control in four months and remained stable up to the sixth month. The conductivity of seeds at $75 \% \mathrm{RH}$ was always higher than that of seeds at $55 \% \mathrm{RH}$, although the differences were small.

Seeds stored at 93\% RH had the lowest values of lipid peroxidation (determined as malondialdehyde, MDA, content) in two months of storage. After the first two months, seeds kept at 75\% RH had the lowest values of lipid peroxidation, followed by seeds at $55 \%$ RH. Lipid peroxidation values at 34\% RH were the highest throughout the storage period (Figure 3). However, differences between samples at 75,55 , and $34 \% \mathrm{RH}$ were small. 

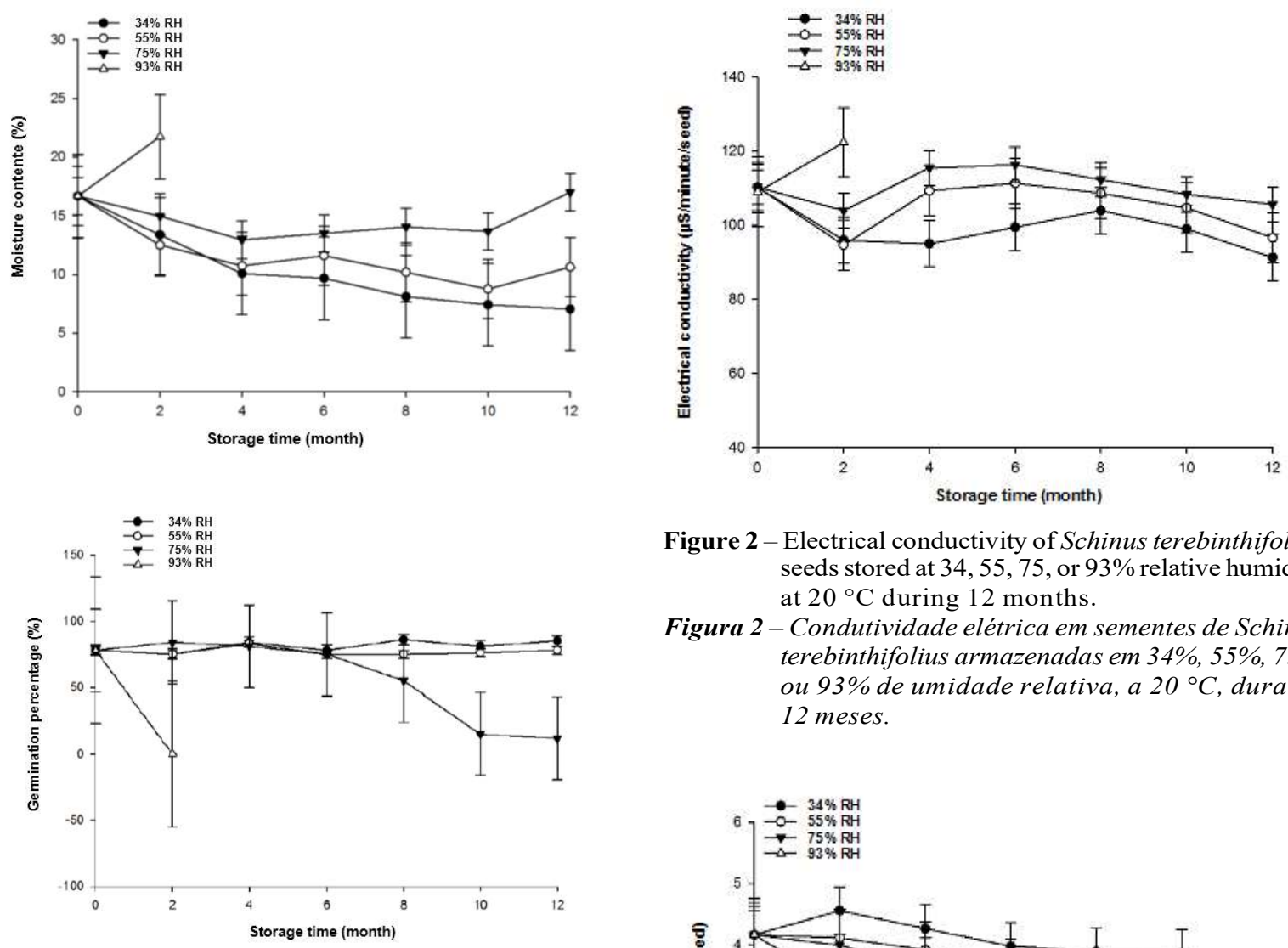

Figure 2 - Electrical conductivity of Schinus terebinthifolius seeds stored at $34,55,75$, or $93 \%$ relative humidity at $20^{\circ} \mathrm{C}$ during 12 months.

Figura 2 - Condutividade elétrica em sementes de Schinus terebinthifolius armazenadas em 34\%, 55\%, 75\% ou $93 \%$ de umidade relativa, a $20^{\circ} \mathrm{C}$, durante 12 meses.

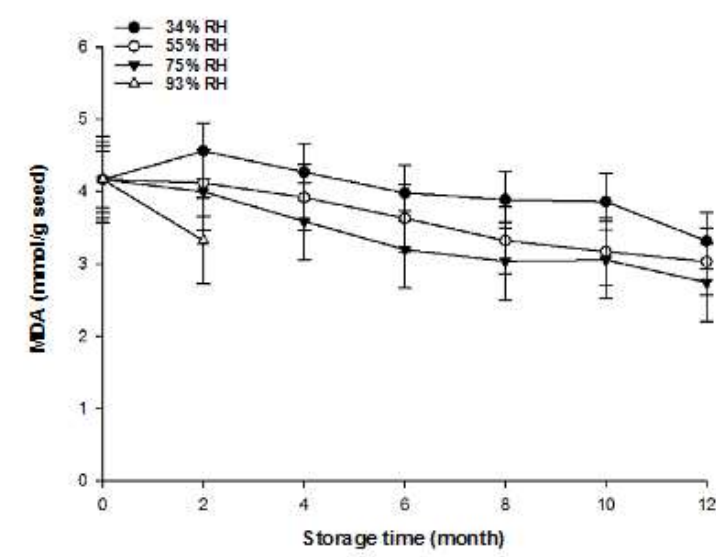

Figure 3 - MDA content of Schinus terebinthifolius seeds stored at $34,55,75$, or $93 \%$ relative humidity at $20{ }^{\circ} \mathrm{C}$ during 12 months.

Figura 3 - Teores de MDA em sementes de Schinus terebinthifolius armazenadas em $34 \%, 55 \%, 75 \%$ ou $93 \%$ de umidade relativa, a $20^{\circ} \mathrm{C}$, durante 12 meses.

Figure 1 - Moisture content, germination percentage, and germination rate of Schinus terebinthifolius seeds stored at $34,55,75$, or $93 \%$ relative humidity at $20{ }^{\circ} \mathrm{C}$ during 12 months.

Figura 1-Teor de água, porcentagem e indice de velocidade de germinação de sementes de Schinus terebinthifolius armazenadas em 34\%, 55\%, 75\% ou 93\% de umidade relativa, a $20^{\circ} \mathrm{C}$, durante 12 meses.

SOD, APX, and CAT activities showed similar behaviors under all studied conditions; no significant differences were observed, except for seeds under $93 \%$ RH, which had increased enzyme activities (Figure 4). Enzyme activities were highest in the second month of analysis.

Revista Árvore. 2018;42(1):e420105 

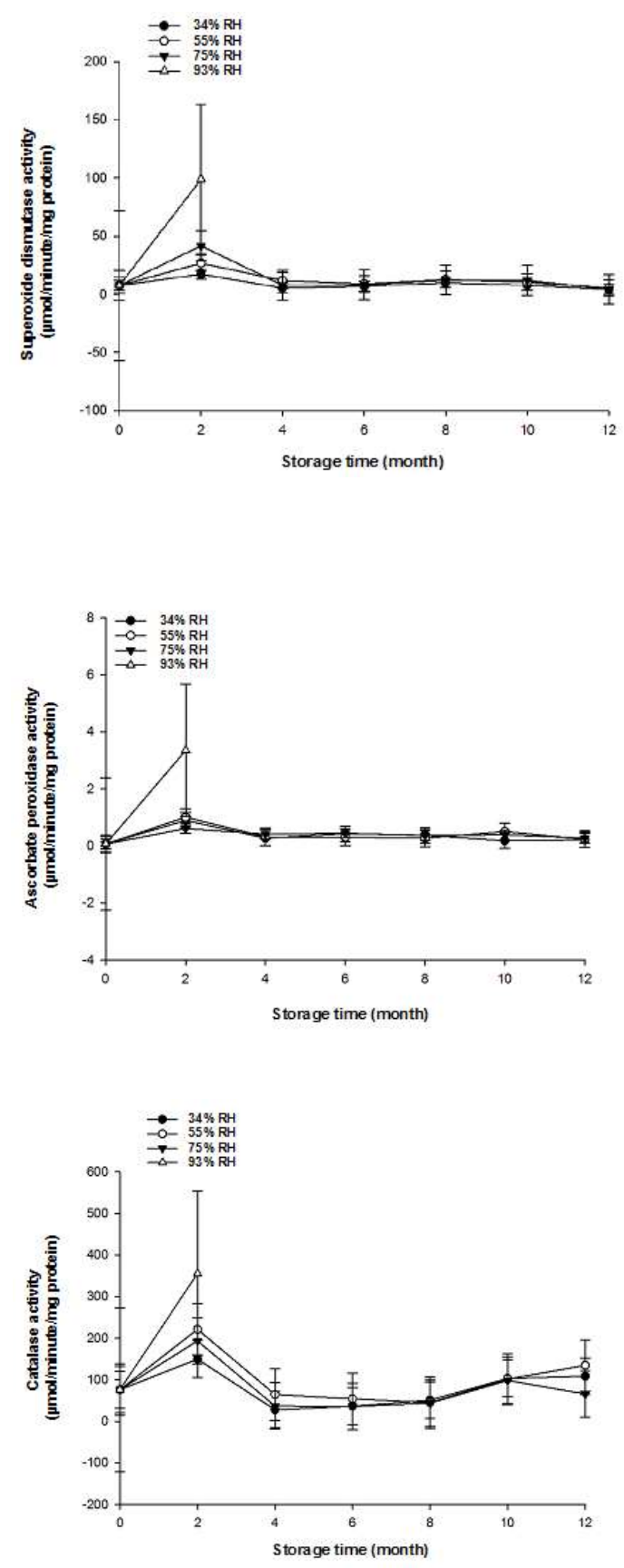

Figure 4 - Superoxide dismutase, ascorbate peroxidase, and catalase activities in Schinus terebinthifolius seeds stored at $34,55,75$, or $93 \%$ relative humidity at $20^{\circ} \mathrm{C}$ during 12 months.

Figura 4-Atividades das enzimas SOD, APXe CAT em sementes de Schinus terebinthifolius armazenadas em $34 \%$, $55 \%, 75 \%$ ou $93 \%$ de umidade relativa, a $20{ }^{\circ} \mathrm{C}$, durante 12 meses.

\section{DISCUSSION}

Brazilian pepper seeds supported a reduction in moisture content without loss of viability or vigor, as shown by the results of seeds stored at $34 \% \mathrm{RH}$, which reached approximately $6 \%$ of moisture and remained viable for 12 months. At $75 \% \mathrm{RH}$, the hygroscopic equilibrium occurred at $16 \%$ moisture content when there was a decline in seed vigor at four months and viability at six months. At moisture contents of approximately $20 \%(90 \% \mathrm{RH})$, loss of vigor occurred in only two months. As seeds were kept at $20^{\circ} \mathrm{C}$, a temperature close to the ideal $\left(25^{\circ} \mathrm{C}\right)$, cell metabolism could be considered appropriate for root protrusion. If this phenomenon does not occur, the seed deteriorates. The same explanation can be applied to seeds at $75 \%$ $\mathrm{RH}$, which showed a similar behavior to seeds stored at $93 \% \mathrm{RH}$ but with a longer survival time.

A low moisture content is recommended for the adequate conservation of seeds of forest species, although optimal values may vary between species. For example, germination was reduced over time in Piptadenia moniliformis seeds stored for 210 days in a controlled environment $\left(18-20^{\circ} \mathrm{C}, 60 \% \mathrm{RH}\right)$ and under uncontrolled laboratory conditions. Seeds kept in the controlled environment, considered the most appropriate, had their germination percentage reduced from $93 \%$ to $86.3 \%$. The initial moisture content, $9 \%$, was increased to $10.2 \%$ at the end of storage time (Benedito et al., 2011). On the other hand, Handroanthus umbellatus seeds with an initial moisture content and germination percentage of $6 \%$ and $93 \%$, respectively, had their moisture content increased to $12.4 \%$ and germination reduced to $25 \%$ after three months of storage at $17-30{ }^{\circ} \mathrm{C}$ and $60-98 \%$ RH (Martins and Pinto, 2014). Ataide et al. (2016) verified that Dalbergia nigra seeds stored at $20^{\circ} \mathrm{C}$ and $55 \%$ $\mathrm{RH}$ maintained their physiological quality, whereas those at $95 \% \mathrm{RH}$ deteriorated in four months.

On the basis of the results with the genera Piptadenia, Handroanthus, and Dalbergia and on those of the present study with $S$. terebinthifolius, it is possible to observe that an increase in moisture content causes a reduction in seed viability.

Electrical conductivity increased as RH increased. This effect was evident in seeds maintained at $93 \% \mathrm{RH}$, which exhibited a complete loss of viability. The reduction in conductivity observed in the second month may be due to a period of hydration that was not sufficient 
to promote electrolyte leakage. In seeds stored at 34\% $\mathrm{RH}$, germination and GR increased as conductivity decreased. The physiological quality of seeds kept at 34 and 55\% RH was similar during the 12-month period, indicating that a 55\% RH environment does not cause damage to the membranes or allows membranes to recover without causing a significant increase in exudation.

At low moisture contents, the melting temperature of phospholipids fatty acids in plasma membranes and tonoplasts increases; membranes change from a liquid crystalline state to a gel state and, therefore, electrolyte leakage occurs. Moisture content at $75 \% \mathrm{RH}$, relatively higher than at 34 and $55 \% \mathrm{RH}$, allowed metabolic reactions to continue, but the embryos did not reach the moisture content necessary for radicle protrusion, leading to death.

These results are in agreement with those obtained with different species. Corte et al. (2010) reported a decrease from 97 to $57 \%$ in the viability of Melanoxylon brauna seeds during storage, which corresponded to a concomitant increase in conductivity. Likewise, electrical conductivity was an efficient indicator of Schinus molle seed quality (Delazeri et al., 2016). In this species, samples with shorter storage times had higher germination percentage and lower conductivity. Annona squamosa seeds stored in permeable containers had a reduction in moisture content and conductivity during the first three months. In this period, the percentage of germination increased (Morais et al., 2011).

Lipid peroxidation had small but continuous reductions over the storage period for decreasing $\mathrm{RH}$ levels, although differences between groups were small. Lipid peroxidation and seed viability showed similar behaviors. These parameters remained stable at 34 and $55 \% \mathrm{RH}$ and decreased at $75 \% \mathrm{RH}$ in eight months of storage, although lipid peroxidation was higher in seeds stored at $34 \% \mathrm{RH}$ and lower at $75 \% \mathrm{RH}$.

According to Bailly et al. (2008), seeds respond differently to ROS within an "oxidative window," which, at limited concentrations, promote seed germination. ROS levels above or below this "oxidative window" can damage cells or are not sufficient to activate relevant metabolic pathways of the germination process. Thus, it is possible that ROS generation facilitated the germination of seeds stored at 34 and $55 \% \mathrm{RH}$ but had a different effect on seeds kept at 75 and $90 \%$ RH. It is not possible to identify the specific metabolic process in which ROS production occurred, as ROS are generated in mitochondria, glyoxysomes, and cell membrane (Sharma et al. 2012).

SOD, CAT, and APX activities remained relatively stable under all tested conditions, especially SOD and APX, which remained at low levels. CAT activity, on the other hand, increased in seeds kept at 34, 55, and $75 \% \mathrm{RH}$ from the ninth month of storage onward until almost reaching the values measured at time zero. Apparently, superoxide and hydroxyl radical levels were not able to trigger the antioxidant defense system. Thus, the reduction observed in vigor and viability of Brazilian pepper seeds after six months at $75 \% \mathrm{RH}$ are due to factors that were not evaluated in the present study.

According to Richards et al. (2015), hydroxyl radical production occurs in the cell wall and in the plasma membrane. Thus, hydroxyl radicals may have played a role in embryo cell death at 75 and $93 \% \mathrm{RH}$, as the enzymes did not present activities that indicated the action of superoxide or hydrogen peroxide.

Results similar to those of the present study were reported by Borges et al. (2015) for Melanoxylon brauna seeds. The authors observed that seeds stored under the same environmental conditions as S. terebinthifolius had a reduction in physiological quality and in SOD and CAT activities at increased RH. No relation was observed between loss of seed quality and lipid peroxidation. On the other hand, Ataide et al. (2012) reported an increase in lipid peroxidation and a reduction in CAT activity and germination in Pterogyne nitens seeds subjected to accelerated aging. The behavior of species varies regarding stress and ROS generation during storage.

\section{CONCLUSION}

Brazilian pepper seeds conserved vigor for 12 months when maintained at 33 and $55 \% \mathrm{RH}$ at $20^{\circ} \mathrm{C}$. An RH of $93 \%$ resulted in seed deterioration in two months. A loss in seed quality was observed after six months of storage at $75 \% \mathrm{RH}$. There was no relationship between loss of physiological quality and lipid peroxidation or membrane permeability.

Acknowledgments: We thank FAPEMIG for the financial support and scholarship grant and Agrorosa for supplying the seeds used in the study. We would also like to thank CNPQ for the productivity grant awarded to E.E.L.B.

Revista Árvore. 2018;42(1):e420105

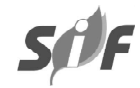




\section{REFERENCES}

Amaral DMI. Padronização de testes de laboratório com sementes florestais. In: Anais do $1^{\circ}$ Simpósio Brasileiro sobre Tecnologia de Sementes Florestais; 1984; Belo Horizonte. Belo Horizonte: ABRATES; 1984. p. 267-83.

Amorim MMR, Santos LC. Tratamento da vaginose bacteriana com gel vaginal de Aroeira (Schinus terebinthifolius Raddi): ensaio clínico randomizado. Rev Bras Ginecol Obstet. 2003;25(2):95-102. http://dx.doi.org/10.1590/S010072032003000200004 .

Anderson MD, Prasad TK, Stewart CR. Changes in isozyme profiles of catalase, peroxidase, and glutathione reductase during acclimation to chilling in mesocotylus of maize seedlings. Plant Physiol. 1995;109(4):1247-57. http://dx.doi.org/ 10.1104/pp.109.4.1247. PMid:12228666.

Araujo JMA. Oxidação de lipídios. Viçosa: UFV, Imprensa Universitária; 1994. 22 p.

Ataíde GM, Borges EEL, Flores AV, Castro RVO. Maintenance of quality of Dalbergia nigra Vell. all. ex. Benth seeds during storage by sodium nitroprusside. J Seed Sci. 2016;38(2):110-7. http:// dx.doi.org/10.1590/2317-1545v38n2156663.

Ataíde GM, Flores AV, Lima e Borges EE. Alterações fisiológicas e bioquímicas em sementes de Pterogyne nitens Tull durante o envelhecimento artificial. Pesqui Agropecu Trop. 2012;42(1):71-6. http://dx.doi.org/10.1590/S198340632012000100010.

Bailly C, El-Maarouf-Bouteau H, Corbineau F. From intracellular signaling networks to cell death: the dual role of reactive oxygen species in seed physiology. C R Biol. 2008;331(10):806-14. http://dx.doi.org/10.1016/j.crvi.2008.07.022. PMid:18926495.

Beauchamp C, Fridovich I. Superoxide dismutase: improved assays and an assay applicable to acrylamide gels. Anal Biochem. 1971;44(1):276-87. http://dx.doi.org/10.1016/0003-2697(71)90370-8. PMid:4943714.

Benedito CP, Ribeiro MCC, Torres SB, Camacho RGV, Soares ANR, Guimarães LMS.
Armazenamento de sementes de Catanduva (Piptadenia moniliformis Benth.) em diferentes ambientes e embalagens. Rev Bras Sementes. 2011;33(1):28-37. http://dx.doi.org/10.1590/S010131222011000100003 .

Borges EEL, Flores AV, Ataíde GM, Matos ACB. Physiological and enzyme activity changes in stored seeds of Melanoylon brauna Schott. Cerne. 2015;21(1):75-81. http://dx.doi.org/10.1590/ 01047760201521011569 .

Borges S, Borges EEL, Correa PC, Brune A. Equilíbrio higroscópico e viabilidade de sementes de angico-vermelho (Anadenanthera peregrina (L) Speng) em diferentes condições ambientais de armazenamento. Sci For. 2009;37(84):475-87.

Bradford MM. A rapid and sensitive method for the quantitation of microgram quantities of protein utilizing the principle of protein-dye binding. Anal Biochem. 1976;72(1-2):248-54. http:// dx.doi.org/10.1016/0003-2697(76)90527-3. PMid:942051.

Brasil. Ministério da Agricultura. Regras para análise de sementes. Brasília: Secretaria Nacional de Defesa Agropecuária; 2009. 399 p.

Corte VB, Borges EEL, Leite HG, Leite ITA. Qualidade fisiológica de sementes de Melanoxylon brauna envelhecidas natural e artificialmente. Sci For. 2010;38(86):181-9.

Cui K, Wang H, Li K, Liao S, Li L, Zhang C. Physiological and biochemical effects of utra-dry storage on Barbados nuts seeds. Crop Sci. 2014;54(4):1748-55. http://dx.doi.org/10.2135/ cropsci2013.10.0680.

Del Longo OT, Gonzáles CA, Pastori GM, Trippi VS. Antioxidant defenses under hyperoxygenic and hyperosmotic conditions in leaves of two lines of maize with differential sensitivity to drought. Plant Cell Physiol. 1993;34:1023.

Delazeri P, Garlet J, Souza GF. Teste de condutividade elétrica em lotes de sementes de Schinus molle L. Floresta Ambient. 2016;23(3):4137. http://dx.doi.org/10.1590/2179-8087.142615.

Flavio JJP, Paula RC. Testes de envelhecimento acelerado e de condutividade elétrica em sementes 
de Dictyoloma vandellianum A.Juss. Sci For. 2010;38(87):391-9.

Flores AV, Borges EEL, Guimarães VM, Gonçalves JFC, Ataíde GM, Barros DP. Atividade enzimática durante a germinação de sementes de Melanoxylon braúna Schott sob diferentes temperaturas. Cerne. 2014;20(3):401-8. http:// dx.doi.org/10.1590/01047760201420031399.

Giannopolitis CN, Ries SK. Superoxide dismutases. Plant Physiol. 1977;59(2):309-14. http://dx.doi.org/10.1104/pp.59.2.309. PMid:16659839.

Guerra MJM, Barreiro ML, Rodriguez ZM, Rubalcada Y. Actividad antimicrobiana de un extracto fluido al $80 \%$ de Schinus terebinthifolius Raddi. Rev Cuba Plantas Med. 2000;5(1):5-23.

Havir EA, McHale NA. Biochemical and developmental characterization of multiple forms of catalase in tobacco leaves. Plant Physiol. 1987;84(2):450-5. http://dx.doi.org/10.1104/ pp.84.2.450. PMid:16665461.

Lenzi M, Orth AI. Caracterização funcional do sistema reprodutivo da aroeira vermelha (Schinus terebinthifolius Raddi), em Florianópolis-SC, Brasil. Rev Bras Frutic. 2004;26(2):198-201. http:// dx.doi.org/10.1590/S0100-29452004000200004.

Maguire JD. Speed of germination: aid in selection and evaluating or seedling emergence and vigour. Crop Sci. 1962;2(2):176-7. http:// dx.doi.org/10.2135/

cropsci1962.0011183X000200020033x.

Marques MA, Paula RC, Rodrigues TJD. Adequação do teste de condutividade elétrica para determinar a qualidade fisiológica de sementes de jacarandá-da-bahia (Dalbergia nigra (Vell.) Fr. All. Ex Benth.). Rev Bras Sementes. 2002;24(1):271-8. http://dx.doi.org/10.1590/S010131222002000100038 .
Martins CC, Pinto MADSC. Armazenamento de sementes de ipê-amarelo-do-brejo (Handroanthus umbellata (Sond.) Mattos Bignoniaceae). Cienc Florest. 2014;24(3):533-9. http://dx.doi.org/10.5902/ 1980509815725 .

Mittler R. Oxidative stress, antioxidants and stress tolerance. Trends Plant Sci. 2002;7(9):40510. http://dx.doi.org/10.1016/S1360-1385(02)023129. PMid:12234732.

Morais OM, Oliveira RH, Oliveira SM, Santos VB, Silva JCG. Armazenamento de sementes de Annona squamosa L. Biotemas. 2011;22(4):33-44. http://dx.doi.org/10.5007/21757925.2009v22n4p33.

Ramalheiro JPSC. Contribuição para a caracterização bioquímica do estado de maturação de azeitonas de diferentes variedades [dissertação]. Universidade Técnica de Lisboa; 2009. $51 \mathrm{p}$.

Richards SL, Wilkins KA, Swarbreck SM, Anderson AA, Habib N, Smith AG, et al. The hydroxyl radical in plants: from seed to seed. $\mathbf{J}$ Exp Bot. 2015;66(1):37-46. http://dx.doi.org/ 10.1093/jxb/eru398. PMid:25294918.

Sadeghipour O, Aghaei P. The role of exogenous salicylic acid (AS) on phytohormonal changes and drought tolerance in common bean (Phaseolus vulgaris L.). J. Bio. Env. Sci. 2012;2(12):8-15.

Scandalios JG. Oxidative stress: molecular perception and transduction of signals triggering antioxidant gene defenses. Braz J Med Biol Res. 2005;38(7):995-1014. http://dx.doi.org/10.1590/ S0100-879X2005000700003. PMid:16007271.

Sharma P, Jha AB, Dubey RS, Pessarakli M. Reactive oxygen species, oxidative dmage, and antioxidative defense mechanism in plant under stressful conditions. J Bot. 2012;26:1-26. 